\title{
SPATIAL VARIATION IN THE MARINE RADIOCARBON RESERVOIR EFFECT THROUGHOUT THE SCOTTISH POST-ROMAN TO LATE MEDIEVAL PERIOD: NORTH SEA VALUES (500-1350 BP)
}

\author{
N Russell ${ }^{1} \cdot \mathrm{G} \mathrm{T} \mathrm{Cook}^{1} \bullet \mathrm{P}$ L Ascough ${ }^{1}$ A J Dugmore ${ }^{2}$
}

ABSTRACT. The marine radiocarbon reservoir effect (MRE) occurs as a spatially and temporally dependent variable owing to localized changes in oceanic water composition. This study investigates $\Delta \mathrm{R}$ values (deviations from the global average MRE whose $\Delta \mathrm{R}=0$ ) during the period 500-1350 BP for the east coast of Scotland, where a complex estuarine system exists that drains into the semi-enclosed North Sea basin. Due to the availability of suitable archaeological samples, the data set has a distinct Medieval focus that spans the area from Aberdeen in the north to East Lothian in the south. Many of the $\Delta \mathrm{R}$ values are not significantly different from 0 (the global average), but there are occasional excursions to negative values ( $\max -172 \pm$ 20 ) indicating the presence of younger water. These values show greater variability compared to other published data for this general region, suggesting that considerable care must be taken when dating marine derived samples from archaeological sites on the east coast of Scotland.

\section{INTRODUCTION}

The marine reservoir effect (MRE) is a ${ }^{14} \mathrm{C}$ age offset between contemporaneous terrestrial and marine samples that arises because of the extended residence time of carbon in the global marine reservoir. The modeled marine calibration curve Marine04 (Hughen et al. 2004) accounts for the global average offset; however, temporal and spatial deviations from this offset, known as $\Delta \mathrm{R}$, are evident. In the absence of suitable terrestrial material, accurate and precise quantification of $\Delta \mathrm{R}$ is imperative for accurate calculation of calendar age ranges based on samples containing marinederived carbon. This is a critical factor in Scottish archaeology where, owing to our island location, prehistoric communities typically exploited a large coastal resource base. Consequently, marinederived material makes a considerable contribution to the national archaeological assemblages. Therefore, if ${ }^{14} \mathrm{C}$ dating has to rely on marine-derived material from any of these sites, it is of paramount importance to ensure good chronological control. Previous studies in the British Isles to determine $\Delta \mathrm{R}$ have been carried out by Ascough et al. (2004, 2005, 2006, 2007a, 2009), Butler et al. (2009), and Harkness (1983) and have produced $\Delta \mathrm{R}$ values varying from -155 off the coast of the Isle of Man (Butler et al. 2009) to +94 off the coast of the Fair Isle (Harkness 1983). These were determined using a range of methodological approaches and highlight the changing nature of the $\mathrm{MRE}$ and the aquatic regimes that drive it. To demonstrate the effect of changing $\triangle \mathrm{R}$ values on radiocarbon calibrations, a hypothetical ${ }^{14} \mathrm{C}$ date of $900 \pm 35 \mathrm{BP}$ was calibrated using OxCal 3.10 (Bronk Ramsey 1995, 2001) with a $\Delta \mathrm{R}$ of +100 , a $\Delta \mathrm{R}$ of -100 and a $\Delta \mathrm{R}$ of 0 , using the Marine 04 curve (Hughen et al. 2004). This produced the variable calendar age ranges shown in Figure 1. Thus, it is evident that $\Delta \mathrm{R}$ has a pronounced effect on the accurate calibration of marine-derived age measurements and any archaeological interpretation that may be based on that dating framework.

Previous research in the SUERC laboratory has investigated the MRE for the Atlantic seaboard from the west coast of Ireland through to the Faroe Isles. This comprehensive investigation of temporal ${ }^{14} \mathrm{C}$ variations within this region, during the Holocene, produced revised $\Delta \mathrm{R}$ values for the west coast of Scotland, northern Iceland, and the Faroes (Ascough et al. 2004, 2006, 2007a,b, 2009).

${ }^{1}$ Scottish Universities Environmental Research Centre, Rankine Avenue, Scottish Enterprise Technology Park, East Kilbride G75 0QF, Scotland.

${ }^{2}$ Institute of Geography, School of Geosciences, University of Edinburgh, Old High School, Infirmary Street, Edinburgh, EH8 9XP, Scotland.

C 2010 by the Arizona Board of Regents on behalf of the University of Arizona

Proceedings of the 20th International Radiocarbon Conference, edited by A J T Jull

RADIOCARBON, Vol 52, Nr 2-3, 2010, p 1166-1181 


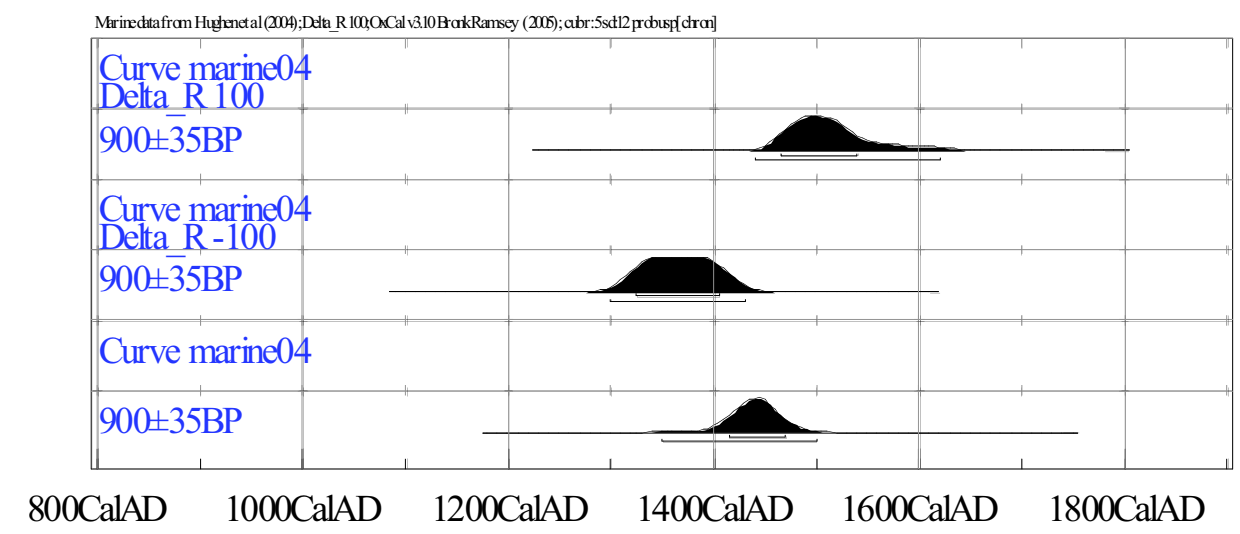

Figure 1 Calibrated age ranges of a $900 \pm 35 \mathrm{BP}$ age measurement showing the difference in resultant calendar age range depending upon the specific $\Delta \mathrm{R}$ value used in the calibration.

Significant re-evaluation and re-interpretation of Scottish archaeological sites followed, where conclusions had previously been drawn that were based on dates from marine-derived carbon (Barber 2003). This allowed crucial re-interpretation of the relationships between Iron Age brochs and wheelhouses in Scotland (Ascough et al. 2004). This current study extends the investigation of MRE to the east coast of Scotland, where a more complex topographical estuarine system exists, draining into the semi-enclosed North Sea basin. The study aimed to assess temporal and spatial variations in $\Delta \mathrm{R}$ within the North Sea basin and to assess consistency (or lack thereof) between $\Delta \mathrm{R}$ values in this region and values from the west coast Atlantic seaboard.

\section{Site Locations}

The sites are all located on the east of Scotland, in close proximity to the North Sea coast, from Aberdeen in the north to East Lothian in the south (Figure 2). The North Sea is a marginal, shallow, shelf sea that lies between the British Isles, Norway, and the European continent, not exceeding depths of $100 \mathrm{~m}$ for most of its extent, except for the Norwegian Trench, which reaches up to $700 \mathrm{~m}$ in depth (Winther and Johannessen 2006). Figure 3 shows the input of water masses to the North Sea with Scottish Coastal Water from the west (SCW (W)) that follows the northern Scottish coast, before turning south to enter the North Sea system (Turrell et al. 1992). The North Sea is fed with Atlantic water (AW) via the English Channel to the south and via the northern boundary, which is subdivided into various input sites including; the Orkney-Shetland section (known as the Fair Isle Current (FIC)), the Shetland shelf and the western part of the Norwegian trench (Winther and Johannessen 2006). A zone of strong tidal mixing occurs around the Orkney Isles, mixing AW and SCW (W), resulting in a fairly homogenous, well mixed FIC flowing towards the Scottish mainland (Turrell 1992). Scottish Coastal Water in the east (SCW (E)) is therefore a composite of SCW (W) and well-mixed FIC deduced by Turrell et al. (1992) to be of the following proportions:

- $\mathrm{SCW}(\mathrm{E}) \quad 85 \% \mathrm{SCW}(\mathrm{w})+15 \% \mathrm{FIC}$.

- SCW (W) $\quad 55 \% \mathrm{AW}+45 \%$ IS/C (Irish /Clyde Seas).

- FIC $66 \% \mathrm{AW}+34 \% \mathrm{SCW}(\mathrm{W})$.

Circulation of North Sea water is mainly cyclonic, flowing south along the British Isles with a divergence along the Norwegian Trench from the northeast of Scotland towards Norway, known as the Dooley Current (DC) (Svendsen et al. 1991). 


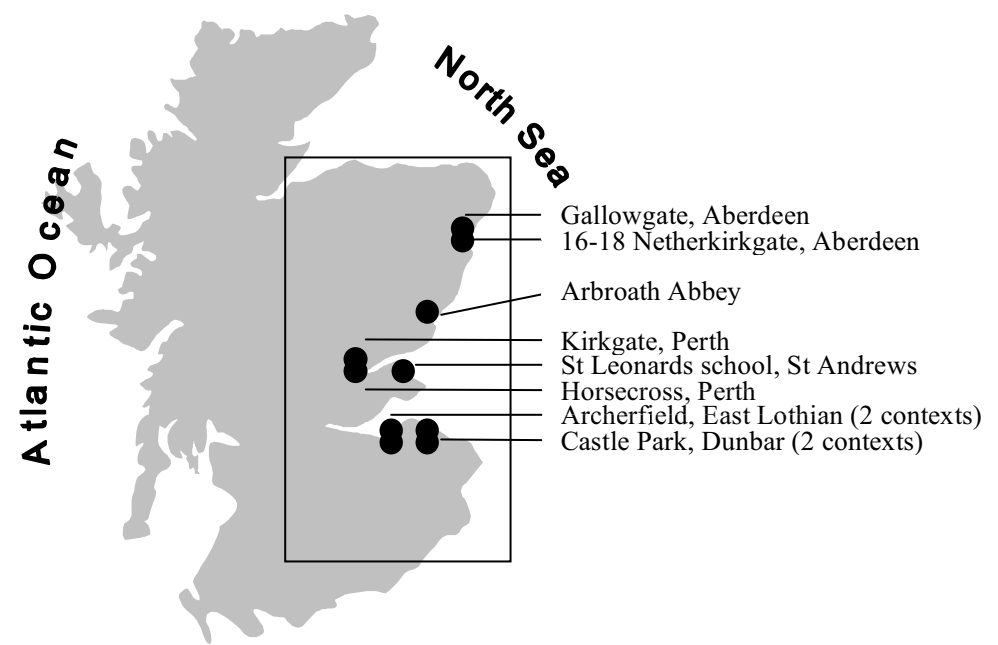

Figure 2 Site locations on the North Sea coast

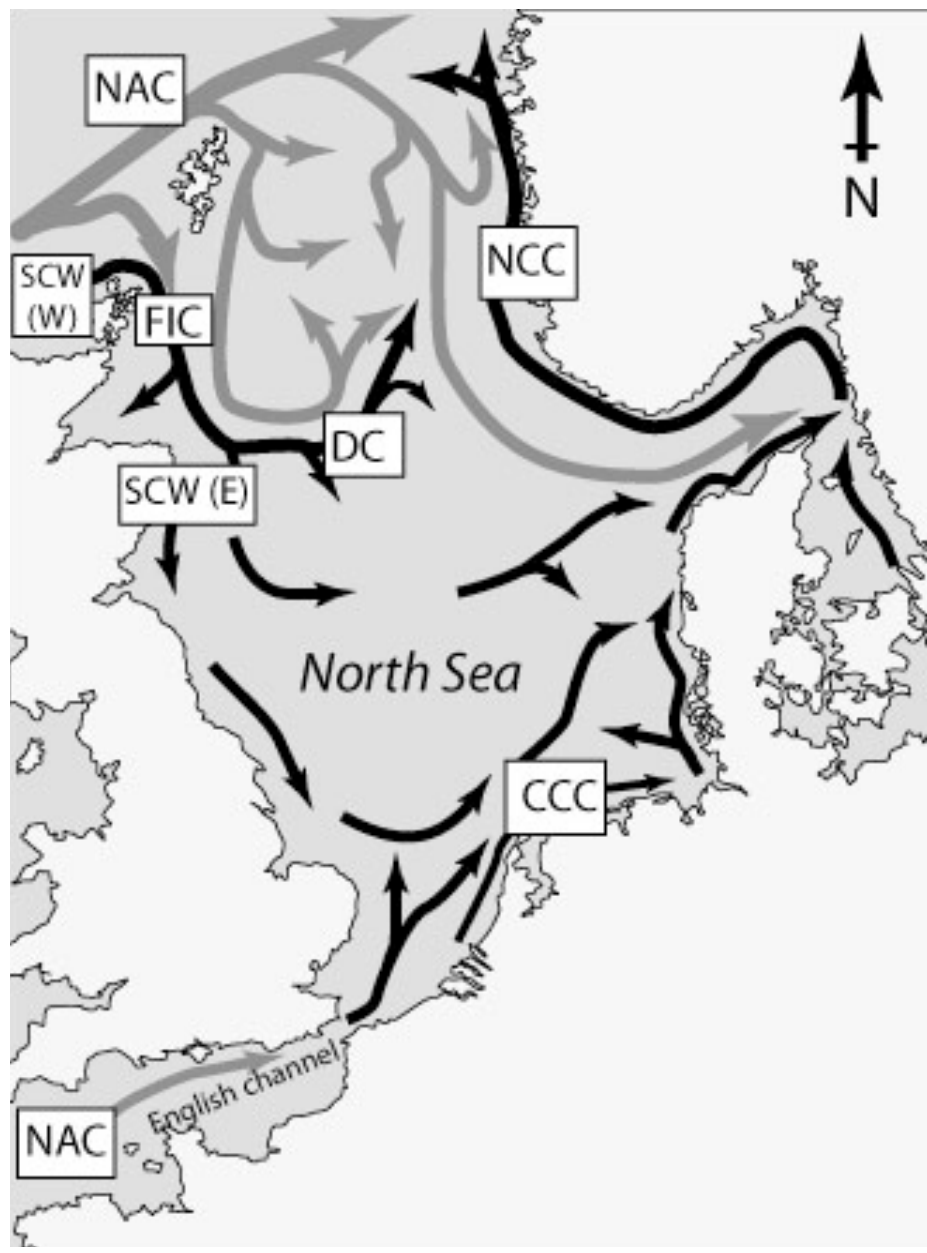

Figure 3 Diagram showing North Sea location and flow of major currents. Gray arrows show Atlantic-derived waters, and black arrows show coastal currents and interior North Sea circulation. NAC: North Atlantic Current; SCW (W): Scottish Coastal Water (West); SCW (E): Scottish Coastal Water (East); FIC (Fair Isle Current); DC: Dooley Current; CCC: Continental Coastal Current; NCC: Norwegian Coastal Current (after Turrell et al. 1992; OSPAR 2000). 


\section{METHODOLOGY}

\section{Samples}

To ensure comparability of the results with previous data for the region, the methodology behind the selection and pretreatment of samples emulated the protocol employed by Ascough et al. (2005, 2006) in previous studies on the Atlantic seaboard of Scotland. Samples were selected from 10 contexts within 8 archaeological sites. The contexts were established as being undisturbed by bioturbation, burrowing, or any kind of intrusive action since deposition via reference to excavation reports and close consultation with site excavators. Each context contained multiple entities of marine and terrestrial material. Contexts that had been laid down over a short period of time (i.e. refuse dumps) were ideal as they could instill confidence that the samples within that context were of the same age, having been deposited at the same time. Provided that there had been no significant disturbance since deposition, these samples could therefore be considered to be contemporary and were consequently suitable for paired sample $\Delta \mathrm{R}$ calculations. The marine material available was invariably mollusk shells and these were carefully examined for any degradation of the carbonate material or organic boring, before selection. Mollusks are typically processed by man close to the site of collection to dispose of the weighty shell component, with only the internal flesh being retained for transport and consumption. Therefore, mollusk shells are considered to be representative of the local coastline where the processing sites are found (Meehan 1982; Waselkov 1987). The terrestrial material available was mainly herbivore bone, presumably owing to preservation conditions, although some carbonized cereal grains were also available. Terrestrial grazing mammals such as cattle and sheep/goats (ovicaprids) were selected to minimize the influence of marine diet from animals with more diverse feeding habits, although studies have shown that grazing herbivores can incorporate a significant marine signal by grazing on material such as seaweed (Ambers 1987). $\delta^{13} \mathrm{C}$ analysis can help identify marine contributions to diet as the values for a purely terrestrial diet in herbivore collagen should be about $-22 \%$ (van der Merwe 1989), whereas a significant marine contribution would result in significantly heavier values (Ambers 1987). All sample material represented entities with a short lifespan (about $<5 \mathrm{yr}$ ), in order to assure similar biological ages of the samples within each context.

Sample pretreatment was employed to ensure that the sample carbon was free from any contaminants. Shell carbonate was pretreated by removing any adhering detritus by physical abrasion before sonication in an ultrasonic bath to remove any further debris. Some $20 \%$ by mass of the outer surface was then removed by etching in $1 \mathrm{M} \mathrm{HCl}$ solution. After rinsing and drying, a 0.1 -g cross-section of the shell, from umbo to shell margin, was selected for acid hydrolysis to integrate the entire lifespan of the organism. The fragments received a further $20 \%$ surface removal, in situ, immediately before hydrolysis, in order to remove any adsorbed $\mathrm{CO}_{2}$ that may have accumulated in the storage period between pretreatment and hydrolysis. The sample $\mathrm{CO}_{2}$ was released by complete acid hydrolysis of the pretreated sample, under vacuum, using an excess of $1 \mathrm{M} \mathrm{HCl}$.

Herbivore bones were subsampled to provide a piece of bone (about 1-2 g) suitable for collagen extraction, which was carried out by a variation of the Longin method (Longin 1971). These subsamples were cleaned using a Dremel ${ }^{\mathrm{TM}}$ drill and sanding bit before immersion in $1 \mathrm{M} \mathrm{HCl}$ at room temperature for roughly $20 \mathrm{hr}$, or until the dissolution of bone phosphate had allowed the sample to become soft and pliable. The acid solution containing the phosphate and any impurities was then decanted without rinsing and the remnant bone material immersed in reverse osmosis water, resulting in a mildly acidic solution. Upon gentle heating, the bone collagen becomes fully soluble and is then filtered, reduced in volume, and freeze-dried prior to combustion and ${ }^{14} \mathrm{C}$ analysis. 
Carbonized cereal grains were subjected to standard acid-base-acid (ABA) pretreatment in order to remove contaminants soluble in each environment. Grains were first heated at $80^{\circ} \mathrm{C}$ for $2 \mathrm{hr}$ in $0.5 \mathrm{M}$ $\mathrm{HCl}$ to remove carbonates and acid soluble contaminants such as fulvic acids. The samples were then decanted, removing the excess acid, and rinsed with water purified by reverse osmosis. The samples were then warmed in dilute $\mathrm{NaOH}(\sim 0.25 \%)$ for an hour to remove any contaminants such as humic acids, which are alkali soluble. This process is not carried out in a nitrogen environment and so absorption of atmospheric $\mathrm{CO}_{2}$ can occur. This was counteracted by a final acid wash, involving a repeat of the first stage of pretreatment. Samples were then thoroughly rinsed using reverse osmosis water and dried, ready for combustion.

Carbon dioxide was obtained from the organic samples by combustion in precleaned, sealed quartz tubes (Vandeputte et al. 1996). The combustion tubes contained quartz wool, supporting $0.5 \mathrm{~g}$ of copper oxide $(\mathrm{CuO})$ and a small length of silver wire. The tubes were evacuated, sealed, and combusted at $850{ }^{\circ} \mathrm{C}$, converting the sample carbon to $\mathrm{CO}_{2}$, using the $\mathrm{CuO}$ as the oxidant and the silver wire to absorb any contaminants such as halides and oxides of nitrogen that are produced (Buchanan and Corcoran 1959).

All $\mathrm{CO}_{2}$ samples were then cryogenically purified using a mixture of ethanol and solid $\mathrm{CO}_{2}$ to freeze down any water vapor, and liquid nitrogen to freeze down the $\mathrm{CO}_{2}$, allowing the removal of noncondensing gases. The vacuum line system employed permitted the subsampling of accurate quantities of $\mathrm{CO}_{2}$ via a calibrated finger to allow a controlled volume $(3 \mathrm{~mL})$ to be collected for graphitization and accelerator mass spectrometry (AMS) measurement, a second sample for $\delta^{13} \mathrm{C}$ analysis, and an archive sample for future assay. The sample $\delta^{13} \mathrm{C}$ was measured off-line using a VG SIRA 10 isotope ratio mass spectrometer, comparing sample values with those of a working standard reference gas of known isotopic composition. The internal reference gas was precalibrated using sample gases of known isotopic composition produced from International Reference Materials such as NBS 19 and IAEA-CO-1. The measurement results were expressed using the $\delta$ notation (Craig 1957) as per mil deviations from the VPDB standard.

${ }^{14} \mathrm{C} /{ }^{13} \mathrm{C}$ ratios of the graphitized samples were measured on the SUERC $250 \mathrm{kV}$ SSAMS (Freeman et al. 2008). All samples from each site were measured within the same batch on the same wheel to reduce any uncertainties attributed to random error. Results were then calculated using the background subtraction method on the ${ }^{14} \mathrm{C} /{ }^{13} \mathrm{C}$ ratio data.

The stable carbon and oxygen isotopic ratios of shell carbonate were measured using a VG Isogas Prism II dual-inlet stable isotope mass spectrometer incorporating a VG Isocarb common acid bath automated carbonate dissolution system, hydrolyzing the samples in 103\% phosphoric acid. Again, the measurement results were expressed using the $\delta$ notation (Craig 1957) as per mil deviations from the VPDB standard, calibrated using the IAEA CO1 (Carrara marble) international standard. The internal analytical precision of the standards was $0.04 \%$ for $\delta^{13} \mathrm{C}$ and $0.08 \%$ for $\delta^{18} \mathrm{O}$.

\section{Statistical Analysis}

The calculated ${ }^{14} \mathrm{C}$ ages were subjected to chi-squared $\left(\chi^{2}\right)$ statistical testing to determine whether each sample within a group was statistically indistinguishable at $95 \%$ confidence from the remainder and therefore considered to be contemporary. The critical value for the $\chi^{2}$ test differs according to the number of measurements within a group and this value is compared to the $T$ statistic for each group to determine whether the samples are statistically indistinguishable (Ward and Wilson 1978). The calculation of the $T$ statistic is shown in Equation 1: 


$$
T=\sum \frac{\left(t_{i}-t\right)^{2}}{\sigma_{i}^{2}}
$$

where $t=$ the weighted mean of the ${ }^{14} \mathrm{C}$ age group; $t_{i}=$ the individual ${ }^{14} \mathrm{C}$ measurement; and $\sigma_{i}=$ the error on the individual measurement.

Where the $T$ statistic for the group was less than the critical value, the samples were considered to be contemporary, whereas where the $T$ statistic was greater than the critical value, the samples were not considered to be internally coherent and so the numbers were subject to more intense scrutiny (see Ascough et al. 2007a.) The method of calculating the $T$ statistic meant that samples that contributed significantly to the $T$ statistic could be identified and discarded.

Ages that passed the $\chi^{2}$ test were then used to calculate $\Delta R$. The $\Delta \mathrm{R}$ value was calculated for every possible pairing of marine/terrestrial samples within a context by converting the terrestrial ${ }^{14} \mathrm{C}$ age $\pm 1-\sigma$ error to modeled marine age bounds. This was achieved using interpolation between the IntCal04 atmospheric curve (Reimer et al. 2004) and the Marine 04 curve (Hughen et al. 2004). The difference between the modeled and the measured marine age (from the measurement of the mollusk shells) is the $\Delta \mathrm{R}$ value. The $1-\sigma$ error on the $\Delta \mathrm{R}$ values is calculated by a propagation of errors shown in Equation 2:

$$
\sigma_{\Delta \mathrm{R}}=\sqrt{ }\left(\sigma_{w}+\sigma_{m}\right)^{2}
$$

where $\sigma_{\Delta \mathrm{R}}=$ the 1- $\sigma$ error for the $\Delta \mathrm{R}$ determination; $\sigma_{w}=$ the error on the measured marine age; and $\sigma_{m}=$ the error on the modeled marine age.

By using every possible pairing, typically 16 estimates of $\Delta \mathrm{R}$ were calculated for each context. A weighted mean was then calculated to give a single representative value for each context, placing more weight on the values with lower associated errors as is commonplace in statistical manipulations. A weighted mean terrestrial age from the multiple terrestrial dates generated for each context was also determined and then calibrated to produce a calendar age range using OxCal 3.10 to provide a calendar age interval for the context.

\section{Results}

All ${ }^{14} \mathrm{C}$ results and $\delta^{13} \mathrm{C}$ results from $\mathrm{CO}_{2}$ subsamples are given in Table 1 . The measured $\delta^{13} \mathrm{C}$ values of the terrestrial mammal bones used within this study ( -19.7 to $-23.1 \%$ ), fall within the typical range for animals existing on purely terrestrial dietary resources in $\mathrm{C}_{3}$-dominated environments (e.g. DeNiro and Epstein 1978; Post 2002). Had there been a significant marine signal within the mammal's diet, this would have been reflected in a heavier $\delta^{13} \mathrm{C}$ signal, which would have caused the rejection of the sample as unrepresentative of a wholly terrestrial sample.

Table $1{ }^{14} \mathrm{C}$ and $\delta^{13} \mathrm{C}$ results for marine and terrestrial samples from each context.

\begin{tabular}{llllc}
\hline \multirow{2}{*}{ Site } & $\begin{array}{l}\text { Lab code } \\
\text { SUERC- }\end{array}$ & Sample material & $\begin{array}{l}{ }^{14} \mathrm{C} \text { age } \\
(\mathrm{BP}) \pm 1 \sigma\end{array}$ & $\begin{array}{l}\delta^{13} \mathrm{C}(\%) \text { relative } \\
\text { to VPDB } \pm 0.1 \% \text { o }\end{array}$ \\
\hline Gallowgate middle school & 17027 & Winkle (Littorina littorea) & $1235 \pm 35$ & 1.9 \\
& 17028 & Winkle (Littorina littorea) & $1195 \pm 35$ & 1.7 \\
& 17029 & Winkle (Littorina littorea) & $1195 \pm 35$ & 2.3 \\
& 17030 & Winkle (Littorina littorea) & $1205 \pm 35$ & 2.0 \\
& 17031 & Ovicaprid tooth & $895 \pm 35$ & -21.0 \\
& 17035 & Ovicaprid tooth & $900 \pm 35$ & -21.1
\end{tabular}


Table $1{ }^{14} \mathrm{C}$ and $\delta^{13} \mathrm{C}$ results for marine and terrestrial samples from each context. (Continued)

\begin{tabular}{|c|c|c|c|c|}
\hline Site & $\begin{array}{l}\text { Lab code } \\
\text { SUERC- }\end{array}$ & Sample material & $\begin{array}{l}{ }^{14} \mathrm{C} \text { age } \\
(\mathrm{BP}) \pm 1 \sigma\end{array}$ & $\begin{array}{l}\delta^{13} \mathrm{C}(\%) \text { relative } \\
\text { to } \mathrm{VPDB} \pm 0.1 \%\end{array}$ \\
\hline & 17036 & Ovicaprid tooth & $935 \pm 35$ & -19.7 \\
\hline & 17037 & Red deer bone unident. & $840 \pm 35$ & -21.7 \\
\hline \multirow[t]{8}{*}{ 16-18 Netherkirkgate } & 17248 & Limpet (Patella vulgata) & $1235 \pm 35$ & 1.7 \\
\hline & 17249 & Limpet (Patella vulgata) & $1270 \pm 35$ & 1.4 \\
\hline & 17250 & Limpet (Patella vulgata) & $1225 \pm 35$ & -0.4 \\
\hline & 17251 & Limpet (Patella vulgata) & $1270 \pm 35$ & 1.5 \\
\hline & 17252 & Ovicaprid tooth & $920 \pm 35$ & -21.6 \\
\hline & 17253 & Ovicaprid tooth & $900 \pm 35$ & -21.2 \\
\hline & 17254 & Cattle tooth & $935 \pm 35$ & -21.1 \\
\hline & 17258 & Hare bone unident. & $995 \pm 35$ & -22.4 \\
\hline \multirow[t]{8}{*}{ Dunbar 0341} & 19094 & Winkle (Littorina littorea) & $1755 \pm 35$ & 1.8 \\
\hline & 19095 & Winkle (Littorina littorea) & $1745 \pm 35$ & -0.1 \\
\hline & 19096 & Winkle (Littorina littorea) & $1700 \pm 35$ & -0.9 \\
\hline & 19097 & Winkle (Littorina littorea) & $1710 \pm 35$ & 0.7 \\
\hline & 19098 & Horse tooth & $1380 \pm 35$ & -22.7 \\
\hline & 19099 & Cattle tooth & $1290 \pm 35$ & -20.7 \\
\hline & 19100 & Ovicaprid tooth & $1320 \pm 35$ & -21.1 \\
\hline & 19104 & Hare bone unident. & $1315 \pm 35$ & -22.2 \\
\hline \multirow[t]{7}{*}{ Dunbar 3017} & 19658 & Winkle (Littorina littorea) & $1450 \pm 35$ & 1.5 \\
\hline & 19659 & Winkle (Littorina littorea) & $1435 \pm 35$ & 1.6 \\
\hline & 19660 & Winkle (Littorina littorea) & $1445 \pm 35$ & 1.0 \\
\hline & 19661 & Winkle (Littorina littorea) & $1485 \pm 35$ & 1.4 \\
\hline & 19106 & Cattle maxilla & $1050 \pm 35$ & -21.4 \\
\hline & 19107 & Ovicaprid tooth & $1125 \pm 35$ & -21.5 \\
\hline & 19108 & Horse tooth & $1110 \pm 35$ & -21.4 \\
\hline \multirow[t]{8}{*}{ Kirkgate, 413} & 18885 & Oyster (Ostrea edulis) & $1040 \pm 35$ & 2.6 \\
\hline & 18886 & Oyster (Ostrea edulis) & $1110 \pm 35$ & 0.7 \\
\hline & 18890 & Oyster (Ostrea edulis) & $990 \pm 35$ & 2.2 \\
\hline & 18891 & Oyster (Ostrea edulis) & $1075 \pm 35$ & 0.2 \\
\hline & 18892 & Ovicaprid bone & $600 \pm 35$ & -23.2 \\
\hline & 18893 & Cattle bone & $645 \pm 35$ & -21.6 \\
\hline & 19719 & Cattle tibia & $640 \pm 35$ & -20.9 \\
\hline & 19720 & Cattle maxilla & $670 \pm 35$ & -21.2 \\
\hline \multirow[t]{16}{*}{ Archerfield, 90} & 19669 & Limpet (Patella vulgata) & $825 \pm 35$ & 0.1 \\
\hline & 19670 & Limpet (Patella vulgata) & $830 \pm 35$ & -2.4 \\
\hline & 19671 & Limpet (Patella vulgata) & $910 \pm 35$ & 0.7 \\
\hline & 19675 & Limpet (Patella vulgata) & $895 \pm 35$ & -1.8 \\
\hline & 19676 & Winkle (Littorina littorea) & $910 \pm 35$ & 1.9 \\
\hline & 19677 & Winkle (Littorina littorea) & $840 \pm 35$ & 1.2 \\
\hline & 19678 & Winkle (Littorina littorea) & $930 \pm 35$ & 0.5 \\
\hline & 19679 & Winkle (Littorina littorea) & $940 \pm 35$ & 1.0 \\
\hline & 19680 & Barley (Hordeum vulgare) & $495 \pm 35$ & -22.4 \\
\hline & 19681 & Barley (Hordeum vulgare) & $470 \pm 35$ & -23.1 \\
\hline & 19685 & Barley (Hordeum vulgare) & $500 \pm 35$ & -24.0 \\
\hline & 19686 & Barley (Hordeum vulgare) & $495 \pm 35$ & -24.1 \\
\hline & 19687 & Oat (Avena sp.) & $485 \pm 35$ & -25.3 \\
\hline & 19688 & Oat (Avena sp.) & $500 \pm 35$ & -24.9 \\
\hline & 19689 & Oat (Avena sp.) & $455 \pm 35$ & -25.0 \\
\hline & 19690 & Oat (Avena sp.) & $525 \pm 35$ & -24.1 \\
\hline
\end{tabular}


Table $1{ }^{14} \mathrm{C}$ and $\delta^{13} \mathrm{C}$ results for marine and terrestrial samples from each context. (Continued)

\begin{tabular}{|c|c|c|c|c|}
\hline Site & $\begin{array}{l}\text { Lab code } \\
\text { SUERC- }\end{array}$ & Sample material & $\begin{array}{l}{ }^{14} \mathrm{C} \text { age } \\
(\mathrm{BP}) \pm 1 \sigma\end{array}$ & $\begin{array}{l}\delta^{13} \mathrm{C}(\%) \text { relative } \\
\text { to } \mathrm{VPDB} \pm 0.1 \% \text { }\end{array}$ \\
\hline \multirow[t]{19}{*}{ Arbroath Abbey } & 16294 & Winkle (Littorina littorea) & $1070 \pm 35$ & 2.2 \\
\hline & 16295 & Winkle (Littorina littorea) & $1095 \pm 35$ & 2.2 \\
\hline & 16296 & Winkle (Littorina littorea) & $1110 \pm 35$ & 2.7 \\
\hline & 16300 & Winkle (Littorina littorea) & $1080 \pm 35$ & 2.6 \\
\hline & 16301 & Oyster (Ostrea edulis) & $1125 \pm 35$ & 2.7 \\
\hline & 16302 & Oyster (Ostrea edulis) & $1095 \pm 35$ & 2.3 \\
\hline & 19705 & Winkle (Littorina littorea) & $1025 \pm 35$ & 2.1 \\
\hline & 19706 & Winkle (Littorina littorea) & $1050 \pm 35$ & 1.2 \\
\hline & 19707 & Winkle (Littorina littorea) & $985 \pm 35$ & 1.3 \\
\hline & 19708 & Winkle (Littorina littorea) & $1045 \pm 35$ & 2.3 \\
\hline & 17041 & Unidentified grain & $690 \pm 35$ & -22.2 \\
\hline & 16284 & Unidentified grain & $695 \pm 35$ & -22.8 \\
\hline & 17045 & Unidentified grain & $645 \pm 35$ & -21.6 \\
\hline & 16286 & Unidentified grain & $670 \pm 35$ & -22.1 \\
\hline & 16291 & Cattle tibia & $685 \pm 35$ & -22 \\
\hline & 19709 & Rabbit tibia & $600 \pm 35$ & -20.8 \\
\hline & 19710 & Ovicaprid humerus & $635 \pm 35$ & -21.2 \\
\hline & 19711 & Ovicaprid humerus & $605 \pm 35$ & -20.6 \\
\hline & 19715 & Ovicaprid humerus & $580 \pm 35$ & -21.1 \\
\hline \multirow[t]{7}{*}{ Archerfield, 142} & 19757 & Winkle (Littorina littorea) & $815 \pm 35$ & 1.4 \\
\hline & 19758 & Winkle (Littorina littorea) & $845 \pm 35$ & 0.9 \\
\hline & 19759 & Limpet (Patella vulgata) & $780 \pm 35$ & 1.2 \\
\hline & 19760 & Barley (Hordeum vulgare) & $500 \pm 35$ & -22.5 \\
\hline & 19761 & Barley (Hordeum vulgare) & $505 \pm 35$ & -22.5 \\
\hline & 19762 & Barley (Hordeum vulgare) & $585 \pm 35$ & -23.1 \\
\hline & 19763 & Oat (Avena sp.) & $495 \pm 35$ & -23.6 \\
\hline \multirow[t]{11}{*}{ Horse Cross } & 16270 & Oyster (Ostrea edulis) & $1040 \pm 35$ & 2.4 \\
\hline & 16271 & Oyster (Ostrea edulis) & $1045 \pm 35$ & 2.4 \\
\hline & 16272 & Oyster (Ostrea edulis) & $1030 \pm 35$ & 2.3 \\
\hline & 16273 & Oyster (Ostrea edulis) & $1065 \pm 35$ & 2.5 \\
\hline & 16274 & Mussel (Mytilus edulis) & $1050 \pm 35$ & 0.6 \\
\hline & 17038 & Mussel (Mytilus edulis) & $1025 \pm 35$ & 1 \\
\hline & 16276 & Cattle distal metacarpal & $640 \pm 35$ & -22.5 \\
\hline & 16282 & Cattle tooth & $665 \pm 35$ & -22.3 \\
\hline & 20276 & Unidentified grain & $640 \pm 35$ & -24.9 \\
\hline & 20277 & Unidentified grain & $555 \pm 35$ & -25.3 \\
\hline & 20278 & Cattle pubic bone & $580 \pm 35$ & -21.8 \\
\hline \multirow[t]{7}{*}{ St Andrews } & 19665 & Winkle (Littorina littorea) & $1475 \pm 35$ & -2.1 \\
\hline & 19666 & Winkle (Littorina littorea) & $1465 \pm 35$ & -1.1 \\
\hline & 19667 & Winkle (Littorina littorea) & $1455 \pm 35$ & -1.5 \\
\hline & 19668 & Winkle (Littorina littorea) & $1420 \pm 35$ & -1.8 \\
\hline & 19109 & Ovicaprid metacarpal & $1235 \pm 35$ & -21.4 \\
\hline & 19110 & Cattle mandible & $1280 \pm 35$ & -21.2 \\
\hline & 21121 & Ovicaprid tibia & $1225 \pm 35$ & -23.1 \\
\hline
\end{tabular}

The ${ }^{14} \mathrm{C}$ results for each context all pass the $\chi^{2}$ test, with $T$ statistics below those of the critical values as shown in Table 2 . This gives confidence that each group of samples is internally coherent and therefore contemporary. Once each group of samples was proven to be contemporary, the various 
pairing of results was used to calculate $\Delta \mathrm{R}$ values and resulted in the production of mean values ranging from $-172 \pm 20$ to $+15 \pm 12$, as shown in Table 3 . This wide range of $\Delta \mathrm{R}$ values spans a temporal extent from $\mathrm{AD} 590-1490$. A weighted mean terrestrial ${ }^{14} \mathrm{C}$ age was derived for each context in order allow calculation of a single calibrated age range and to tie each context to a particular archaeological period.

Table 2 Results of $\chi^{2}$ testing on each context.

\begin{tabular}{lcccc}
\hline Site & $\begin{array}{l}\text { Terrestrial } \chi^{2} \\
T \text { value }\end{array}$ & $\begin{array}{l}\text { Critical } \\
\text { value }\end{array}$ & $\begin{array}{l}\text { Marine } \chi^{2} \\
T \text { value }\end{array}$ & $\begin{array}{l}\text { Critical } \\
\text { value }\end{array}$ \\
\hline Gallowgate middle school & 4.04 & 7.81 & 0.98 & 7.81 \\
16-18 Netherkirkgate & 4.10 & 7.81 & 1.35 & 7.81 \\
Dunbar 0341 & 3.79 & 7.81 & 1.92 & 7.81 \\
Dunbar 3017 & 2.62 & 5.99 & 1.33 & 7.81 \\
Kirkgate, 413 & 2.17 & 7.81 & 6.36 & 7.81 \\
Archerfield, 90 & 2.67 & 14.07 & 12.82 & 14.07 \\
Arbroath Abbey & 12.16 & 15.5 & 13.00 & 16.9 \\
Archerfield, 142 & 4.45 & 9.49 & 1.66 & 5.99 \\
Horse Cross & 6.71 & 9.49 & 0.81 & 11.07 \\
St Andrews & 1.31 & 5.99 & 1.58 & 7.81 \\
\hline
\end{tabular}

Table 3 Calculated dates and $\Delta \mathrm{R}$ values for each site.

\begin{tabular}{lclrrl}
\hline & Weighted mean & Cal age range & Mean & & General time \\
Site & terrestrial age (BP) & $2 \sigma(\mathrm{AD})$ & \multicolumn{1}{l}{$\Delta \mathrm{R}$} & $\pm 1 \sigma$ & period \\
\hline Archerfield, 90 & $492 \pm 22$ & $1380-1490$ & -42 & 5 & Medieval \\
Archerfield, 142 & $520 \pm 43$ & $1290-1460$ & -130 & 13 & Medieval \\
Horse Cross & $616 \pm 45$ & $1290-1410$ & 15 & 12 & Medieval \\
Kirkgate, 413 & $639 \pm 30$ & $1270-1410$ & 8 & 17 & Medieval \\
Arbroath Abbey & $644 \pm 43$ & $1250-1430$ & 7 & 7 & Medieval \\
Gallowgate middle school & $892 \pm 41$ & $1020-1270$ & -57 & 17 & Medieval \\
16-18 Netherkirkgate & $938 \pm 41$ & $980-1220$ & -95 & 14 & Norse/Medieval \\
Dunbar 3017 & $1094 \pm 40$ & $800-1040$ & 1 & 14 & Norse \\
St Andrews & $1246 \pm 28$ & $670-880$ & -172 & 20 & Pictish/early Norse \\
Dunbar 0341 & $1326 \pm 39$ & $590-780$ & 4 & 14 & Pictish \\
\hline
\end{tabular}

\section{DISCUSSION}

Due to the availability of suitable archaeological samples, the data presented is mainly Medieval in nature and spans most of the east coast of Scotland from the most northerly site in Aberdeen to the most southerly in East Lothian. Many of the $\Delta \mathrm{R}$ values are consistent around 0 (the global average), but there are occasional excursions to negative values indicating the presence of water that is less depleted in ${ }^{14} \mathrm{C}$. These variations in $\Delta \mathrm{R}$ are often attributed to spatial or temporal relationships owing to local geology or topography influencing the carbon content of the surrounding waters or events influencing ocean regimes at certain times (Kennett et al. 1997; Kovanen and Easterbrook 2002; Ascough et al. 2006).

It can be observed in Figure 4 that although apparent spatial groupings of similar $\Delta \mathrm{R}$ values are broadly evident, closer investigation does not reveal significant positive correlation with topographical or geological features such as estuarine environments or limestone-rich areas that could influence the ${ }^{14} \mathrm{C}$ content of local waters. The majority of the east coast of Scotland displays a sandstone- 
rich geology, avoiding any major outcrops of calcareous rocks, although some small seams may be present in Aberdeenshire (Geological Map Data $\mathbb{C}$ NERC 2010). However, this does not sufficiently explain the significant deviations visible in the $\Delta \mathrm{R}$ values, as significant shifts in $\Delta \mathrm{R}$ values occur between individual sites even in areas with very similar geology, i.e. Archerfield and Dunbar.

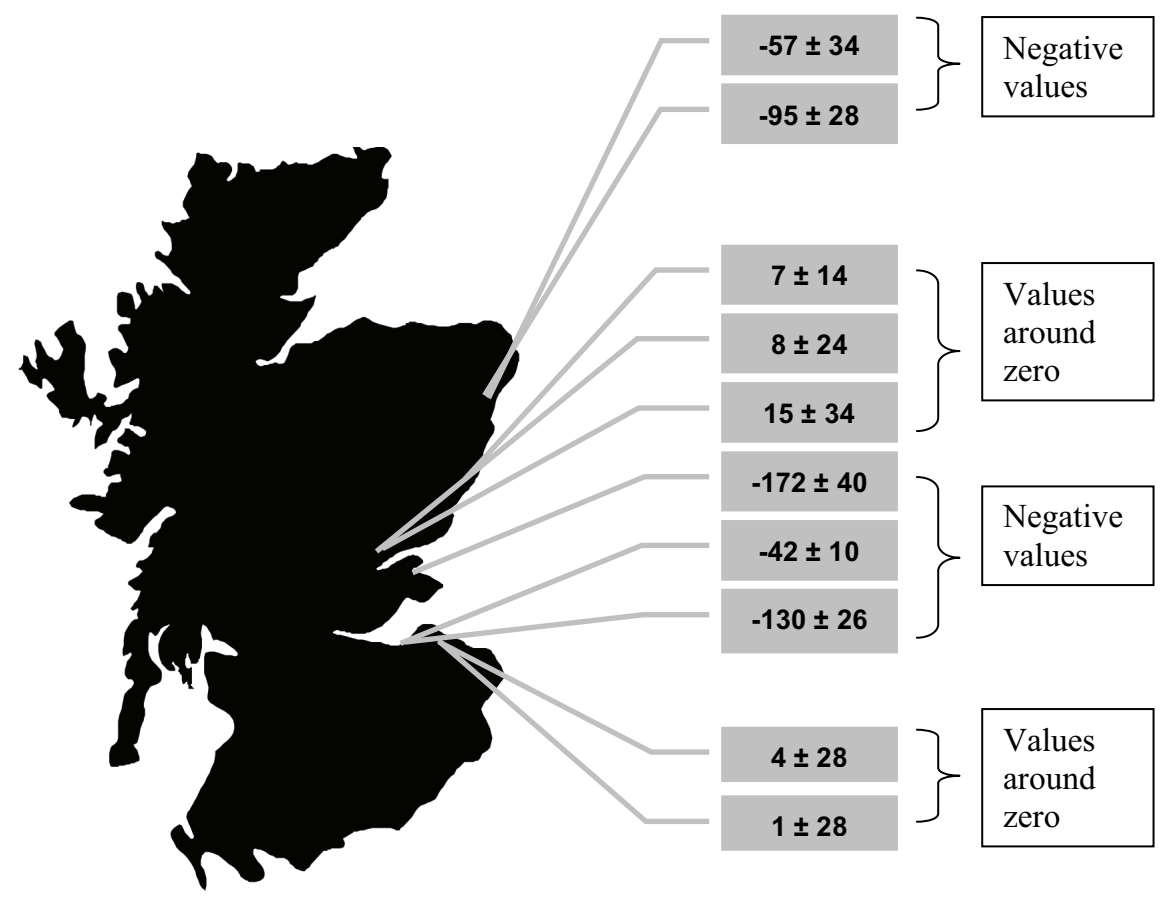

Figure 4 Spatial distribution of $\Delta \mathrm{R}$ values.

One source of variability in the $\Delta \mathrm{R}$ values may be differences in freshwater input, given the extensive runoff to the North Sea from the east coast of Scotland. It is assumed that shells precipitate their carbonate in equilibrium with the surrounding water and so can provide isotopic data for the ambient seawater (Epstein et al. 1953). Therefore, shell data were used to investigate whether the variation in $\Delta \mathrm{R}$ values was a function of freshwater input to the environment in which the shells had grown.

The majority of the east coast of Scotland has extensive riverine networks that ultimately discharge into the North Sea. Many of the minor rivers discharge directly into the sea, although the major rivers have a tendency to form estuarine environments, known as firths, shown in Figure 5. The mean annual freshwater input to the Scottish North Sea Coastal Zone (SNSCZ) from the major Scottish rivers is shown in Table 4 to demonstrate the relative importance of local freshwater fluxes (Lyons et al. 1993; Scottish Environment Protection Agency, http://www.sepa.org.uk). The total maximum discharge to the North Sea in winter was calculated at $\sim 1380 \mathrm{~m}^{3} \mathrm{~s}^{-1}$ (Lyons et al. 1993).

Studies by Lyons et al. (1993) regarding the importance of riverine input to the SNSCZ proposed that $45 \%$ of the mean freshwater discharge to the North Sea originated from the Moray Firth via the Inverness Firth, Cromarty Firth, and River Spey. However, it is notable that current meters from the same study have indicated that water from the Moray Firth does not follow the along-shore route south, but is directed east towards the tidal mixing zone of the Buchanan front in the central North Sea. This results in a much-reduced input from the north to the rest of the coastal waters on the east 


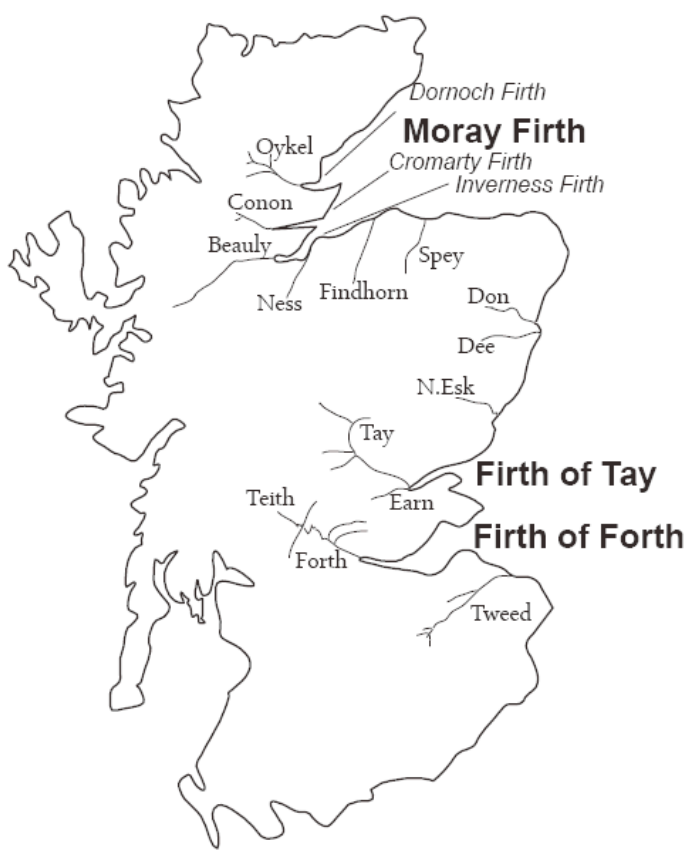

Figure 5 Major Scottish rivers draining into the North Sea with mean freshwater discharges over $15 \mathrm{~m}^{3} \mathrm{~s}^{-1}$ (after Lyons et al. 1993).

Table 4 Mean freshwater discharge rates of major Scottish rivers (1987-91) with outputs over $15 \mathrm{~m}^{3} \mathrm{~s}^{-1}$ (Lyons et al. 1993.)

\begin{tabular}{lc}
\hline River & Mean freshwater discharge $\mathrm{m}^{3} \mathrm{~s}^{-1}$ \\
\hline Tay & 183.3 \\
Ness & 97.7 \\
Tweed & 77.0 \\
Spey & 64.5 \\
Conon & 57.2 \\
Beauly & 54.4 \\
Dee & 42.3 \\
Teith & 33.5 \\
Earn & 29.3 \\
Findhorn & 20.3 \\
Forth & 16.8 \\
Don & 16.5 \\
N.Esk & 16.3 \\
Oykel & 15.6 \\
\hline
\end{tabular}

of Scotland. A further $25 \%$ of the total freshwater input to the SNSCZ was contributed by the Firth of Tay, showing the dominance of 2 specific environments to the freshwater flux to the SNSCZ. These 2 inputs are therefore responsible for the major addition of freshwater masses to the coastal water in the east, which itself is derived from coastal water from the west, and a small contribution from the FIC. As none of the sites investigated are found to the north of the Moray Firth, interpretation of shell $\delta^{18} \mathrm{O}$ values from sites within this study relies on the composition of the coastal water masses and the influences of the freshwater environments south of the Moray Firth.

In order to determine whether the variability in $\Delta \mathrm{R}$ values (i.e. from within error of zero, to significant negative excursions) could be attributed to freshwater input alone, the mean $\delta^{18} \mathrm{O}$ values of the 
shells was examined to see if any direct correlation could be drawn. The shells were crushed and homogenized and so the samples measured were assumed to be representative of the mean $\delta^{18} \mathrm{O}$ signal of the shell. It is well known that shells have seasonality of growth and with this comes variability in $\delta^{18} \mathrm{O}$ values, but the purpose of this experiment was merely to determine whether groups of shells that were showing significant negative excursions in $\Delta \mathrm{R}$ values also showed evidence for a freshwater input in mean $\delta^{18} \mathrm{O}$ values. Such a result would support the interpretation that these shells grew in surrounding water with lower ${ }^{14} \mathrm{C}$ activity (due to a freshwater input) than shells from sites with less-negative $\Delta \mathrm{R}$ values. ${ }^{14} \mathrm{C}$ levels can vary in the coastal zone due to the mixing of freshwater containing modern carbon with the ambient seawater, or mixing of freshwater containing "old carbon" components from the terrestrial environment with the ambient seawater. The first of these possibilities would result in a net increase of local seawater ${ }^{14} \mathrm{C}$, while the second would result in a net decrease of local seawater ${ }^{14} \mathrm{C}$. Either of these factors (or a combination of both) can lead to varying levels of ${ }^{14} \mathrm{C}$ in specific locales, therefore driving the localized changes visible in the $\Delta \mathrm{R}$ determinations. A representative value for the $\delta^{18} \mathrm{O}$ of the surrounding water for a shell was calculated based upon the measured shell carbonate $\delta^{18} \mathrm{O}$ using Equation 3 (Epstein et al. 1953):

$$
\left.\delta^{18} \mathrm{O}_{\mathrm{w}}=\delta^{18} \mathrm{O}_{\mathrm{C}}-((16.9-T) / 4.38)\right)
$$

where $\delta^{18} \mathrm{O}_{\mathrm{w}}=$ derived water $\delta^{18} \mathrm{O} ; \delta^{18} \mathrm{O}_{\mathrm{C}}=$ measured shell carbonate $\delta^{18} \mathrm{O}$; and $T=$ average water temperature.

The derived value of $\delta^{18} \mathrm{O}_{\mathrm{w}}$ was converted to the SMOW scale using the relationship: $\delta^{18} \mathrm{O}_{\mathrm{w}}$ $(\mathrm{VPDB})=\delta^{18} \mathrm{O}_{\mathrm{w}}(\mathrm{SMOW})-0.27$ (Hut 1987). The average temperature of $8.5^{\circ} \mathrm{C}$ was chosen on the basis of CEFAS (Centre for Environment, Fisheries and Aquaculture Science, http://www.cefas. co.uk/) data for surface waters in the North Sea. It is acknowledged that temperature can vary in the coastal waters investigated, but as most of the shells are from a similar time period and with the lack of precise climatic information for this period, it was felt that we were justified in using this mean temperature. Any large shifts in sea surface temperature between groups of samples from different time periods would have been shown in proxy records from the time and any shifts in mean temperature across the data set would have forced the results in the same direction. Essentially, the purpose of the investigation was to identify any large $\delta^{18} \mathrm{O}$ differences within the data set that were obviously attributable to significant freshwater input and therefore potentially leading to the changes in $\Delta \mathrm{R}$.

Ocean water salinity and $\delta^{18} \mathrm{O}$ are proportionally related for the study region as shown in Figure 6 , using the mixing line for the North Sea region as generated by Austin et al. (2006) using $\delta^{18} \mathrm{O}_{\mathrm{w}}=$ $0.18^{*} \mathrm{~S}-6.0$. The calculated sample ${ }^{18} \mathrm{O}_{\mathrm{w}} \mathrm{SMOW}$ values were plotted on the salinity mixing line as shown below to determine whether values were representative of open coastal $/$ marine water with high salinity or freshwater with low salinity.

It can be observed that all of the values calculated from shell $\delta^{18} \mathrm{O}$ values from the 8 sites are located in the high salinity position on the mixing line. It would appear from these data that none of the shells within the sample set were grown within water with a significant freshwater input; therefore, freshwater input is unlikely to be an underlying cause of the variability in $\Delta \mathrm{R}$ values. As no positive correlation could be observed between the $\Delta \mathrm{R}$ values and the geographical distribution of the sites and proximity to freshwater input the possibility of a temporal relationship seemed the next logical step of investigation.

Knowing that proxy data and climatic records show peak British temperatures towards the end of the 12th century BC followed by a general cooling towards the Little Ice Age of the Late Medieval/ Early Modern period (1564-1730s) (Reiter 2000), it was hypothesized that these climatic changes 


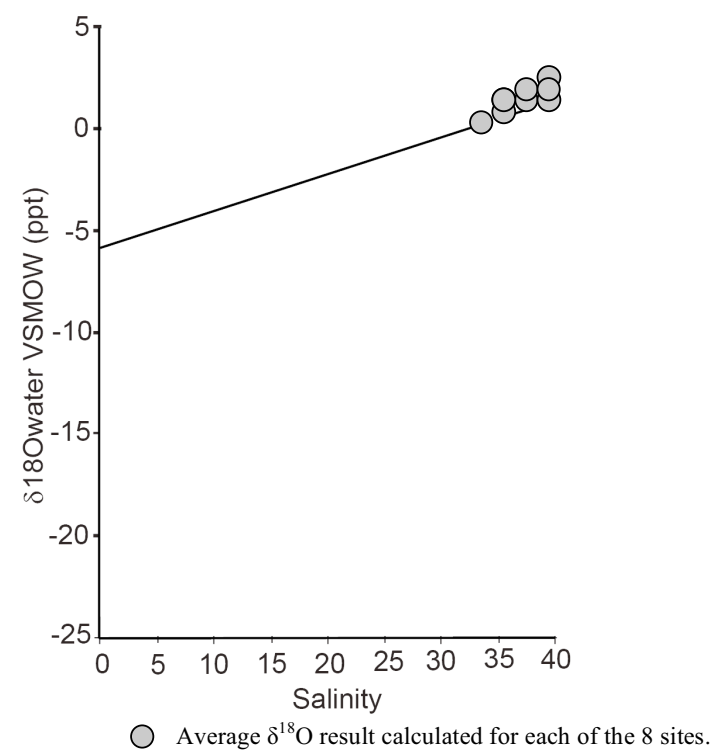

Figure 6 Relationship between $\delta^{18} \mathrm{O}_{\mathrm{w}}$ and salinity (after Austin et al. 2006), showing the calculated values for

could be allied with oceanic circulation shifts resulting in variation in the composition of water entering the North Sea. Such variation would be a potential cause of changes in $\Delta \mathrm{R}$. However, the results from Table 3 and the plotted data in Figure 7 show that no directly proportional relationship exists between $\Delta \mathrm{R}$ and terrestrial age.

As North Sea coastal water originates from west coast waters with a small Atlantic input via the FIC, the possibility exists that the shifts in $\Delta \mathrm{R}$ may act as a proxy for shifts in Atlantic values at the same time and therefore indicate shifts in circulatory patterns and/or sources of Atlantic water as shown in previous studies where oceanic circulatory changes are marked by variations in $\Delta \mathrm{R}$ values (Bersch et al. 2007; Hakkinen and Rhines 2009). The North Sea data presented here shows greater variability than the consistently negative data produced by Ascough et al. (2004) for the Atlantic Middle Iron Age in Scotland where the average $\Delta \mathrm{R}=-79 \pm 17$. As the east coast water is composed mainly of water derived originally from the west coastal zone, the expectation would be that values should be similar, or perhaps show similar trends and/or variability in the data. Complicated mixing processes in estuarine environments on the east coast of Scotland are evident from studies of Scottish Firths (Balls 1992, 1994), but preliminary oxygen isotope data suggest that major freshwater contributions are not evident in the shells and therefore freshwater input is not an obvious cause of the variations in $\Delta \mathrm{R}$.

The remaining possibility is therefore that Atlantic water entering the North Sea has experienced changes in composition or perhaps magnitude throughout the periods investigated in this study, leading to varying levels of ${ }^{14} \mathrm{C}$ in North Sea surface waters. The small direct Atlantic contribution to the SNSCZ provided by the FIC is coupled with SCW (W), also Atlantic derived, which provides the major constituent of SCW (E) and so short, sharp shifts in AW may be readily apparent in the North Sea water. The possibilities remain that either the $\Delta \mathrm{R}$ for the region is around zero, with excursions to negative values caused by incursions of less-depleted water or that the $\Delta \mathrm{R}$ value for the region is indeed negative and therefore more similar to the west coast values published by Ascough et al. (2004), with incursions of more-depleted water. The consistency in the data for $\Delta \mathrm{R}$ values around zero when compared to the more variable negative values would suggest that the changes in $\Delta \mathrm{R}$ are being driven by incursions of less-depleted water of marine origin. 


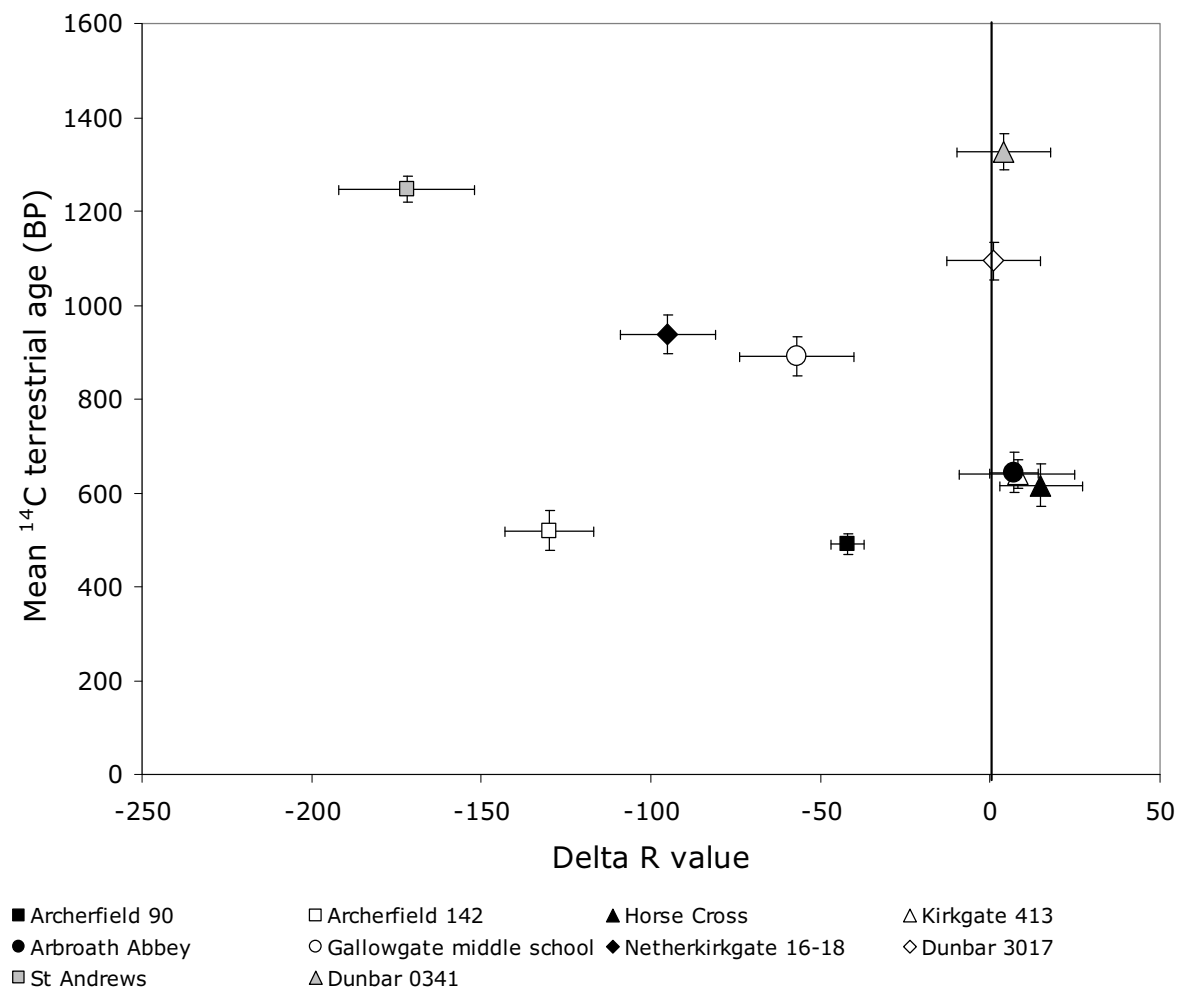

Figure 7 Temporal relationships in $\Delta \mathrm{R}$ values $\pm 2 \sigma$

Previous large-scale changes in the composition of North Sea water have been documented, such as the Great Salinity Anomaly, which involved a decrease in North Sea salinities during the mid- to late 1970s. This was explained by Dickson et al. (1988) as alteration of the mean pressure over the European Arctic resulting in an increase of Arctic water flowing to the south, thus reducing the temperature and salinity of the waters to the east of Greenland (Turrell 1992). It was then counteracted by Turrell et al. (1992) as being the result of the coincidence of a drop in production of $18^{\circ}$ mode water (water with homogenous salinity, density, and temperature of $\sim 18^{\circ} \mathrm{C}$ ) in the Sargasso Sea, forcing a decline in the Gulf Stream and therefore the supply to the North Sea when coupled with extremely low westerly winds. These depleted currents then followed the circulatory system of the North Atlantic, and into the North Sea. This relatively recent shift in the composition of North Sea water may support our hypothesis of previous changes in Atlantic water composition causing shifts in $\Delta \mathrm{R}$ values.

\section{CONCLUSIONS}

The variable values of $\Delta \mathrm{R}$ obtained for the North Sea within the period from about 500 to $1350 \mathrm{BP}$ (about AD 600 to 1500), ranging from -172 to $+15{ }^{14} \mathrm{C} \mathrm{yr}$, show little positive correlation with time. The spatial relationship of the $\Delta \mathrm{R}$ values at first appears to show faint groupings of values within error of zero, and values that are significantly negative. These spatial groupings do not appear attributable to any obvious topographic or geological features that could affect the ${ }^{14} \mathrm{C}$ content of local waters. The possibility of the changes in $\Delta \mathrm{R}$ manifesting themselves as a direct result of proximity to an estuarine location was investigated via ${ }^{18} \mathrm{O}$ analysis; however, there was no variation in the results that could explain the range in $\Delta \mathrm{R}$ values as being directly related to a significant freshwater input. 
This leaves 2 possible reasons for the shift in $\Delta \mathrm{R}: 1)$ that the $\Delta \mathrm{R}$ for the region is close to zero, with the excursions to negative values being driven by the incursion of younger, less-depleted Atlantic water during relatively rapid, local events; or 2) that the $\Delta \mathrm{R}$ for the region is negative, although exceedingly variable with the excursions to zero values being driven by the incursion of older, moredepleted Atlantic water. The apparent stability in the data for $\Delta \mathrm{R}$ values around zero would support the first statement. The second hypothesis is supported by observations that previous incursions of older water to the area have been documented, i.e. the Great Salinity Anomaly; however, it is not supported by the fact that the negative $\Delta \mathrm{R}$ values are very variable. Therefore, the most likely underlying mechanism for the $\Delta \mathrm{R}$ values observed in this study is that the $\Delta \mathrm{R}$ for the region is around zero with episodes of less-depleted water of marine origin entering the North Sea system. The source of these events driving the changes in Atlantic source water to the North Sea is as yet unknown, but provides the focus for further study in this region alongside further investigation of estuarine processes in order to understand the variability in $\Delta \mathrm{R}$ for the region. Finally, this study demonstrates the care required when dealing with marine-based carbon from this region and the consequent calibration of ${ }^{14} \mathrm{C}$ ages using assumed $\Delta \mathrm{R}$ values for the North Sea.

\section{ACKNOWLEDGMENTS}

The authors acknowledge NERC (NE/F002211/1) and Historic Scotland for funding. We would also like to thank the Scottish Urban Archaeological Trust (SUAT Ltd), AOC Archaeology Group and Aberdeen City Council for the provision of samples and in particular Catherine Smith and Derek Hall of SUAT Ltd for the identification of samples. Thanks are also given to the staff of the SUERC Radiocarbon Dating and AMS Laboratories for ${ }^{14} \mathrm{C}$ measurements and to Terry Donnelly for help with ${ }^{18} \mathrm{O}$ analyses.

\section{REFERENCES}

Ambers JC. 1987. Identification of the use of marine plant material as animal fodder by stable isotope ratios. In: Mook WG, Waterbolk HT, editors. Proceedings of the 2 nd international symposium on ${ }^{14} \mathrm{C}$ and Archaeology, Strasbourg, France. PACT 29:251-8.

Ascough P, Cook GT, Dugmore AJ, Barber J, Higney E, Scott EM. 2004. Holocene variations in the Scottish marine radiocarbon reservoir effect. Radiocarbon 46(2):611-20

Ascough P, Cook GT, Dugmore AJ. 2005a. Methodological approaches to determining the marine radiocarbon reservoir effect. Progress in Physical Geography 29(4):532-47.

Ascough PL, Cook GT, Dugmore AJ, Scott EM, Freeman SPHT. 2005b. Influence of mollusk species on marine $\Delta \mathrm{R}$ determinations. Radiocarbon 47(3):433-40.

Ascough P, Cook G, Church MJ, Dugmore AJ, Arge SV, McGovern TH. 2006. Variability in North Atlantic marine radiocarbon reservoir effects at c. AD 1000. The Holocene 16(1):131-6.

Ascough PL, Cook GT, Dugmore AJ, Scott EM. 2007a. The North Atlantic marine reservoir effect in the Early Holocene: implications for defining and understanding MRE values. Nuclear Instruments and Methods in Physics B 259(1):438-47.

Ascough PL, Cook GT, Church MJ, Dugmore AJ, McGovern TG, Dunbar E, Einarsson Á, Friðriksson A, Gestsdóttir H. 2007b. Reservoirs and radiocarbon: ${ }^{14} \mathrm{C}$ dating problems in Mývatnssveit, northern Iceland. Radiocarbon 49(2):947-61.

Ascough P, Cook GT, Dugmore AJ. 2009. North Atlantic marine ${ }^{14} \mathrm{C}$ reservoir effects: implications for late-Holocene chronological studies. Quaternary Geochronology 4(3):171-80.

Austin WEN, Cage AG, Scourse JD. 2006. Mid-latitude shelf seas: a NW European perspective on the seasonal dynamics of temperature, salinity and oxygen isotopes. The Holocene 16(7):937-47.

Balls PW. 1992. Nutrient behaviour in two contrasting Scottish estuaries, the Forth and the Tay. Oceanologica Acta 15(3):261-77.

Balls PW. 1994. Nutrient inputs to estuaries from nine Scottish east coast rivers; influence of estuarine processes on inputs to the North Sea. Estuarine Coast Shelf Science 39(4):329-52.

Barber J. 2003. Bronze Age farms and Iron Age farm mounds of the Outer Hebrides. Scottish Archaeological Internet Reports (SAIR) 3. The Society of Antiquaries of Scotland. URL: http://www.sair.org.uk/ sair3. Accessed 20 December 2009.

Bersch M, Yashayaev I, Koltermann KP. 2007. Recent changes of the thermohaline circulation in the subpolar North Atlantic. Ocean Dynamics 57(3):223-35.

Bronk Ramsey C. 1995. Radiocarbon calibration and analysis of stratigraphy: the OxCal program. Radiocarbon 37(2):425-30. 
Bronk Ramsey C. 2001. Development of the radiocarbon calibration program. Radiocarbon 43(2A):355-63.

Buchanan DL, Corcoran B. 1959. Sealed tube combustions for the determination of carbon-13 and total carbon. Analytical Chemistry 31:1635-17.

Butler PG, Scourse JD, Richardson CA, Wanamaker AD, Bryant CL, Bennell JD. 2009. Continuous marine radiocarbon reservoir calibration and the ${ }^{13} \mathrm{C}$ Suess effect in the Irish Sea: results from the first multi-centennial shell-based marine master chronology. Earth and Planetary Science Letters 279(3-4):230-41.

Craig H. 1957. Isotopic standards for carbon and oxygen and correction factors for mass-spectrometric analysis of carbon dioxide. Geochimica et Cosmochimica Acta 12(1-2):133-49.

DeNiro MJ, Epstein S. 1978. Influence of diet on the distribution of carbon isotopes in animals. Geochimica et Cosmochimica Acta 42(5):495-506

Dickson RR, Meinke J, Malmberg SA, Lee AJ. 1988. The 'Great Salinity Anomaly' in the northern North Atlantic 1968-1982. Progress in Oceanography 20(2):103-51.

Epstein S, Buchsbaum R, Lowenstam H, Urey HC. 1953. Revised carbonate water isotopic temperature scale. Geological Society of America Bulletin 64:1315-26.

Freeman SPHT, Dougans A, McHargue L, Wilcken KM, $\mathrm{Xu}$ S. 2008. Performance of the new single stage accelerator mass spectrometer at the SUERC. Nuclear Instruments and Methods in Physics Research B 266(10):2225-8.

Geological Map Data (C NERC. 2010. Available at URL: http://edina.ac.uk/digimap/index.shtml.

Hakkinen S, Rhines PB. 2009. Shifting surface currents in the northern North Atlantic Ocean. Journal of Geophysical Research 114: C04005, doi:10.1029/ 2008JC004883.

Harkness DD. 1983. The extent of the natural ${ }^{14} \mathrm{C}$ deficiency in the coastal environment of the United Kingdom. PACT 8:351-64.

Hughen KA, Baillie MGL, Bard E, Beck JW, Bertrand CJH, Blackwell PG, Buck CE, Burr GS, Cutler KB, Damon PE, Edwards RL, Fairbanks RG, Friedrich M, Guilderson TP, Kromer B, McCormac G, Manning S, Bronk Ramsey C, Reimer PJ, Reimer RW, Remmele S, Southon JR, Stuiver M, Talamo S, Taylor FW, van der Plicht J, Weyenmeyer CE. 2004. Marine04 marine radiocarbon age calibration, 0-26 cal kyr BP. Radiocarbon 46(3):1059-86.

Hut G. 1987. Consultants Group Meeting on Stable Isotope Reference Samples for Geochemical and Hydrological Investigations, Report to the Director General. Vienna: International Atomic Energy Agency. 42 p.

Kennett DJ, Ingram L, Erlandson JM, Walker P. 1997. Evidence for temporal fluctuations in marine radiocarbon reservoir ages in the Santa Barbara Channel, southern California. Journal of Archaeological Science 24(11):1051-9.

Kovanen DJ, Easterbrook DJ. 2002. Paleodeviations of radiocarbon marine reservoir values for the northeast Pacific. Geology 30(3):243-6.

Longin R. 1971. New method of collagen extraction for radiocarbon dating. Nature 230(5291):241-2.

Lyons MG, Balls PW, Turrell WR. 1993. A preliminary study of the relative importance of riverine nutrient inputs to the Scottish North Sea Coastal Zone. Marine Pollution Bulletin 26(11)620-8.

Meehan B. 1982. Shell Bed to Shell Midden. Canberra: Australian Institute of Aboriginal Studies. 117 p.

OSPAR Commission. 2000. Quality Status Report 2000. London: OSPAR Comission. 108 p.

Post DM. 2002. Using stable isotopes to estimate trophic position: models, methods, and assumptions. Ecology 83(3):703-18.

Reimer PJ, Baillie MGL, Bard E, Bayliss A, Beck JW, Bertrand CJH, Blackwell PG, Buck CE, Burr GS, Cutler KB, Damon PE, Edwards RL, Fairbanks RG, Friedrich M, Guilderson TP, Hogg AG, Hughen KA, Kromer B, McCormac G, Manning S, Bronk Ramsey C, Reimer RW, Remmele S, Southon JR, Stuiver M, Talamo S, Taylor FW, van der Plicht J, Weyhenmeyer CE. 2004. IntCal04 terrestrial radiocarbon age calibration, 0-26 cal kyr BP. Radiocarbon 46(3):1029-58.

Reiter P. 2000. From Shakespeare to Defoe: malaria in England in the Little Ice Age. Emerging Infectious Diseases 6(1).

Svendsen E, Sætre R, Mork M. 1991. Features of the northern North Sea circulation. Continental Shelf Research 11(5):493-508.

Turrell WR. 1992. New hypotheses concerning the circulation of the northern North Sea and its relation to North Sea fish stock recruitment. ICES Journal of Marine Science 49(1):107-23.

Turrell WR, Henderson EWR, Slesser G, Payne R, Adams RD. 1992. Seasonal changes in the circulation of the northern North Sea. Continental Shelf Research 12(2-3):257-86.

van der Merwe NJ. 1989. Natural variation in ${ }^{13} \mathrm{C}$ concentration and its effect on environmental reconstruction using ${ }^{13} \mathrm{C} /{ }^{12} \mathrm{C}$ ratios in animal bones. In: Price TD, editor. The Chemistry of Prehistoric Human Bone. Cambridge: Cambridge University Press. p 105-25.

Vandeputte K, Moens L, Dams R. 1996. Improved sealed-tube combustion of organic samples to $\mathrm{CO}_{2}$ for stable carbon isotope analysis, radiocarbon dating and percent carbon determinations. Analytical Letters 29(15):2761-73.

Ward GK, Wilson SR. 1978. Procedures for comparing and combining radiocarbon age determinations: a critique. Archaeometry 20(1):19-31.

Waselkov GA. 1987. Shellfish gathering and shell midden archaeology. Advances in Archaeological Method and Theory 10:93-210.

Winther NG, Johannessen JA. 2006. North Sea circulation: Atlantic inflow and its destination. Journal of Geophysical Research. 111: C12018, doi:10.1029/ 2005JC003310. 